\title{
On differences in Enterprise Resource Planning implementation between manufacturing and services: an empirical study
}

\section{Farshad Salimi*}

Reprocess Limited, UK

Jan ter Laanplaats $20 \mathrm{~A}$,

3063 RT, Rotterdam, The Netherlands

E-mail: farshad@re-process.com

*Corresponding author

\section{Ben Dankbaar}

Radboud University Nijmegen, Institute for Management Research, PO Box 9108, 6500 HK, Nijmegen, The Netherlands E-mail: b.dankbaar@fm.ru.nl

\begin{abstract}
In this article, we empirically review differences in Key Success Factors (KSFs) between manufacturing and services. In a systematic presentation of 12 case studies, we identify differences in the reasons for Enterprise Resource Planning (ERP) adoption as well as differences in KSFs in ERP implementation between manufacturing and services. As a result, we draw conclusions on differences in ERP implementation methodologies between manufacturing and service sectors.
\end{abstract}

Keywords: Enterprise Resource Planning; ERP; implementation; Key Success Factors; KSFs; manufacturing, services.

Reference to this paper should be made as follows: Salimi, F. and Dankbaar, B. (2009) 'On differences in Enterprise Resource Planning implementation between manufacturing and services: an empirical study', Int. J. Intercultural Information Management, Vol. 1, No. 4, pp.383-406.

Biographical notes: Farshad Salimi is a Process Specialist and Team Leader in the Process Industries as well as an MBA Lecturer at several European MBA schools. He has a PhD from the Radboud University Nijmegen.

Ben Dankbaar is Professor of Business Administration at the Radboud University Nijmegen, The Netherlands. He is a Director of the Centre for Innovation Studies in the Institute for Management Research and member of the Board of the Institute for Science, Innovation and Society, both at the Radboud University Nijmegen.

Copyright (C) 2009 Inderscience Enterprises Ltd. 


\section{Introduction}

In the course of the 1990s, Enterprise Resource Planning (ERP) systems evolved when the functionality of Material Requirements Planning (MRPII) in production was blended with other applications concerning quality, maintenance, marketing, sales, personnel and various other support activities. Thus, ERP systems moved away from the manufacturing environment to support of the entire manufacturing company and from there to the support of service companies as well. These changes in functionality and application environment have had an important impact on implementation processes for these systems.

A number of authors identified a variety of factors that could be considered as critical to the success of an ERP implementation (Umble et al, 2003). Nah, Zuckweller and Lau (2003) stated that the high failure rate of ERP implementation called for a better understanding of its Key Success Factors (KSFs; Somers, Nelson and Ragowsky, 2000). Nah, Zuckweller and Lau (2003) identified 11 KSFs from an extensive literature review; then they used this result as a benchmark to evaluate a survey of chief information officers' perceptions of the degree of criticality of these KSFs' for ERP implementation. Nah, Zuckweller and Lau's (2003) identification of the KSFs and their citations by ERP practitioners point to knowledge accumulation and convergent opinions of both academics and practitioners.

We review differences by key components of the project route to ERP implementation - such as differences in reasons for ERP adoption, project content (i.e. in $\mathrm{KSFs}$ ) and project goals.

\section{Research methodology}

We tackled the research objective in a series of consecutive, longitudinal and iterative case studies. First, we applied several comprehensive and short questionnaires. Then, we carried out in-depth research case studies within firms, followed by a second round of short questionnaires during implementation and a third round of interviews during post-implementation periods.

A review of the literature showed that most KSFs were based on snap shots taken in ERP implementation at the project level. Most of the earlier research work has been conducted at a single point of time and it usually involved one stakeholder.

In contrast to this, most ERP projects were multi-year projects with project goals changing continuously in the turbulent market. As a result, the KSFs also changed along with this changing process. We investigated these changes in KSFs and project goals for firms implementing ERP packages over the past eight years.

We carried out longitudinal studies where we observed an exponential learning curve in the process of ERP implementation at international firms. We observed an iterative feedback control loop to the preceding phases. With this kind of correction mechanism and subsequent readjustments of actions, the impact of KSFs changed accordingly along the ERP project route. In that perspective, the KSFs found in the literature provide only a weak indication of the potential problems. 
We argue that the research methodology and resulting models of earlier research like the models of stage-phase constructed by Markus and Tanis (2000), Al-Mashari, Al-Mudiningh and Zairi (2003) and earlier models by Kwon and Zmud (1987) and SAP (1999) failed to incorporate;

1 the continuous development of ERP systems

2 medium to small size firms in most industries

3 a thorough and specific definition and application of the stage model for each project

4 together with the impact of iterative processes on the phases and the project content

5 differences in impact of the KSFs along the project route.

Markus and Tanis (2000) proposed an intermediate research methodology between indepth case studies and survey methodology to overcome this kind of limitations. In a way, our study with a combination of pilot, in-depth, and incidental (one-to-three interviews with no follow-up) case studies, case papers (pilot case studies with specific goals) and interviews (generic and non-generic, prior and post-ERP implementation), approached the research methodology proposed by Markus and Tanis (2000).

\subsection{Empirical research approach}

We divided the in-depth research cases into four groups (Figure 1). In the following review of this empirical research, we look into the differences in ERP implementation between manufacturing and services. Our observations and the case studies in ERP implementation suggest that ERP implementation in the service sector is not the same as in the manufacturing sector. For effective implementation of an ERP system, e.g. SAP, it is necessary to differentiate carefully between the implementation processes in manufacturing and in services.

The empirical approach method is based on the grouping of empirical cases and narrowing down the differences between the cases, primarily in KSFs, moving from groups (1) to (4). The four groupings of in-depth empirical cases are classified on the basis of several criteria with group (1) showing the largest differences (i.e. small or large firm, tailor-designed ERP system or package and service or manufacturing) and group (4) showing a few differences (i.e. only service firms).

The differences diminish from group (1) with differences in manufacturing and services, tailor-designed and packages and small and large, to group (2) with differences in manufacturing and service, and tailor-designed and package, to group (3) with the difference between manufacturing and services and finally to group (4) with a few differences covering only cases in the service sector.

\section{Empirical findings}

\subsection{Review of cases}

\subsubsection{Group (1)}

In group (1), we grouped the four cases with differences in terms of manufacturing and services, tailor-designed and packages, and small and large (Table 1). 
Figure 1 Grouping of empirical cases by narrowing down differences from Groups (1) to (4)

\section{EXHIBITS}

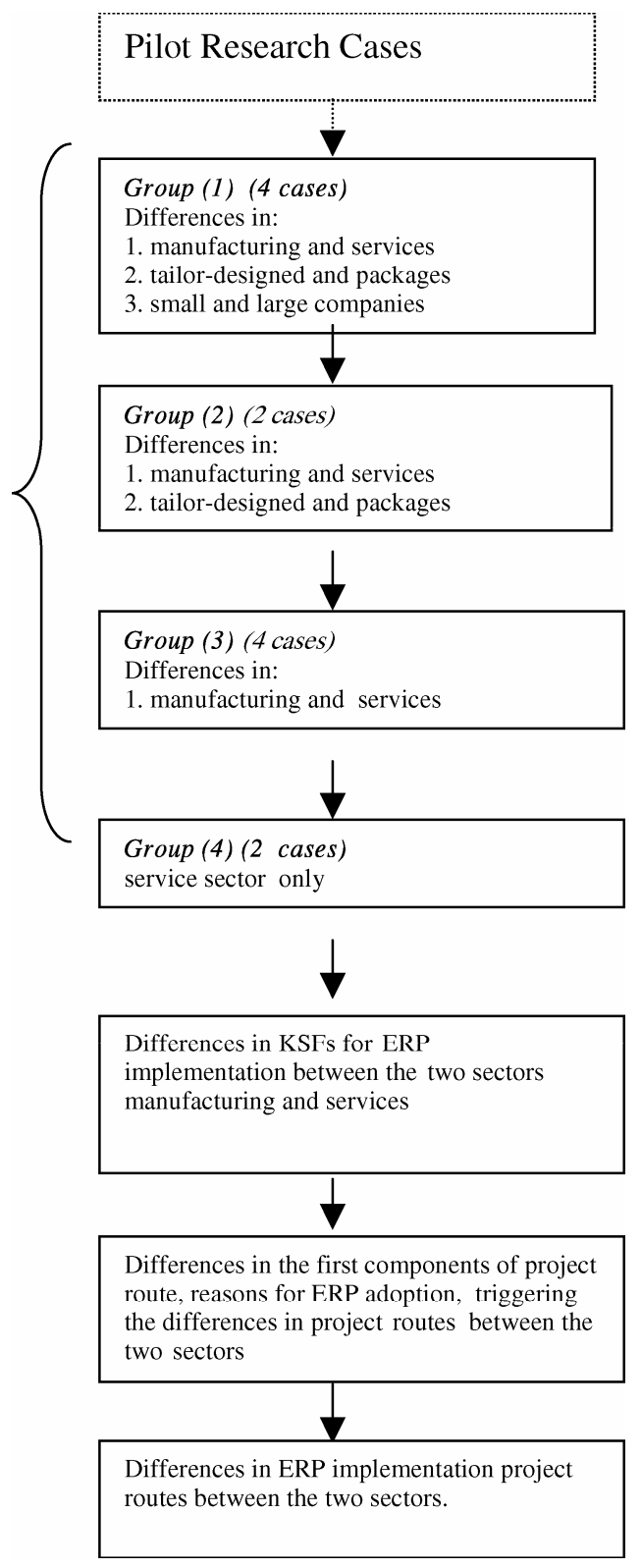


Table 1 Review of Enterprise Resource Planning implementation in four cases (Group 1)

\begin{tabular}{lllll}
\hline Companies & Revenue & ERP Vendor & Project Budget & ERP Modules implemented \\
\hline$\alpha$ & Euro-3.0 M & $\begin{array}{l}\text { SAP/BaanIV/ } \\
\text { Pentagon }\end{array}$ & Euro 8.0 M & Maintenance module \\
$\beta$ & Euro 2.0 Billion & SAP & Euro 2.5 M & $\begin{array}{l}\text { S\&D, purchasing, finance, } \\
\text { WMS }\end{array}$ \\
$\phi$ & Euro 21.0 M & Exact & Euro 0.2 M & Finance, project control \\
$\sigma$ & Euro 0.5 M & $\begin{array}{l}\text { Microsoft } \\
\text { access/SQL } \\
\text { system }\end{array}$ & Euro 50000 & $\begin{array}{l}\text { Database management } \\
\text { system, documentation }\end{array}$ \\
\hline
\end{tabular}

$\alpha$ is a service firm in the aviation industry. $\alpha$ has been through a continuous innovative restructuring process to survive in the shrinking competitive aviation maintenance industry. $\alpha$ implemented SAP R/2 and BaaN IV prior to the millennium in order to cut back on its Maintenance, Revision and Overhaul (MRO) costs and to boost its efficiency in its internal processes.

The replacement of SAP R/2 with BaaN IV took a period of 12 months and it was completed in the beginning of 1999. $\alpha$ is a unique case of a rational approach by restructuring internal processes to aim at internal cost savings across the supply chain together with external orientation to suppliers and clients.

In each phase of restructuring, $\alpha$ shifted its ERP system: from SAP R/2 to BaaN IV and then to Pentagon based on the three criteria:

1 continuous improvement processes

2 new business strategy

3 organisational fit.

Even during the Pentagon implementation, the firm executed a business case analysis for post-Pentagon implementation improvements. $\alpha$ conducted two parallel processes with ERP Pentagon implementation superseding the BaaN IV package, and a business case analysis for futurisation. The $\alpha$ case is an example of a thoroughly professional approach to ERP implementation. $\alpha$ worked continuously in its internal and external structure to respond to client demands.

$\beta$ is a manufacturing firm with food production sites worldwide. $\beta$ successfully implemented and rolled out the first SAP modules of sales and distribution at three production sites in the Netherlands. ERP SAP implementation took 18 months, (started in November 2001), and it went live in two steps in April 2003 and June 2003, several months ahead of the planned schedule in August 2003. The problem of rapid expansion in production volume and the reliance of $70 \%$ of sales on a small client portfolio was the critical problem in the $\beta$ operation. In its earlier structure, $\beta$ lost profits because of a rapid expansion without a relevant structure. The potato processing industry is a highly technical and knowledge intensive industry. It requires state-of-the-art and high-tech hardware systems, such as optisort defect removers, peeling equipment, packaging equipment, etc. for the fully automated processing side. Later, $\beta$ used knowledge management as a business solution approach in ERP implementation to solve the critical problems in its operation. 
$\phi$ is an international manufacturing firm with a manufacturing site in the Netherlands. The core product is a transport vehicle, automated guided vehicle while the core business is software development and industrial automation. $\phi$ implemented four systems, ERP exact financials (i.e. inventory control and accounting), super office (i.e. a Customer Relationship Management (CRM) groupware database system), Linux (i.e. a system development unit) and internet access (i.e. component selection, online-communication and online-procurement). The core business, software development, is a complex process, which is difficult to plan and control. $\phi$ has been carrying out a business case study to restructure internal business processes for standardisation of software development tasks. The co-investigator stated,

"The first step in our efforts towards external focus, e-business, is standardisation of the business processes at $\phi$ ".

$\sigma$ is a small service firm in facility consulting. The reasons for IT integration were; standardisation of business processes to futurisation of hidden assets, and coping with business growth. In this process, $\sigma$ customised and extended the Microsoft access and SQL program for standardisation of its internal business processes. The result of investment in IT integration on such a small scale was improvement in quality while other aspects remained unchanged.

\subsubsection{Group (2)}

In group (2), we grouped two cases with differences in terms of manufacturing and services, tailor-designed and packages (Table 2).

$\mu$ is a manufacturing firm with worldwide shoe production sites and retail businesses. $\mu$ spent six months on business case analysis, three months on training and education, and approx. seven months in customisation. $\mu$ implemented the first SAP sales and distribution module in July 1999 . Over the past years, $\mu$ has successfully implemented and rolled out many SAP modules in a stage-wise implementation process. $\mu$ was pushed to implement an IT integrated business solution for its expansion and competitive position in the global market. $\mu$ began with a clear approach in business analysis and a clear identification of the business processes which SAP should support. They worked with the ASAP method of SAP to implement the first modules of finance, and sales and distribution in Denmark, Indonesia and Slovakia. They rolled out the modules to other 11 countries. $\mu$ implemented the SAP production module prior to rollout at its 25 locations worldwide.

Table 2 Review of Enterprise Resource Planning implementation in two cases (Group 2)

\begin{tabular}{lllll}
\hline Companies & Revenue & ERP vendor & Project budget & ERP modules implemented \\
\hline$\Pi$ & Non-disclosure & Own designed & Euro 0.5 mil & $\begin{array}{l}\text { ERP CRM-audit } \\
\text { agent/balanced scorecard }\end{array}$ \\
$\mu$ & $\begin{array}{l}3.5 \text { billion } \\
\text { Danish kroon }\end{array}$ & SAP & Non-disclosure & SAP modules \\
\hline
\end{tabular}


$\Pi$ is a service firm with groups of accountants, management consultants and financial and legal advisors. $\Pi$ initiated the development of JvZnet, Module audit agent (annual report, intermediate report, operation report and budget prognosis) and Module balanced scorecard (balanced scorecard and benchmarking). For the first time, $\Pi$ implemented this new CRM to its client site $\varepsilon$ in July 2001. The implementation was successful and the post-implementation benefits to the two firms were remarkable. $\Pi$ licensed its in-house tailor-designed ERP JvZnet system and it marketed this product primarily to its clients and to the rest of the market.

\subsubsection{Group (3)}

In group (3), we grouped four cases with differences in terms of manufacturing and services (Table 3 ).

$\chi$ is a manufacturing firm in chemical, petrochemical and bulk chemicals with worldwide production sites. $\chi$ implemented the first SAP module in finance in June 1995. For the first version of SAP modules, $\chi$ spent many months in restructuring internal business processes, and training and education of dedicated personnel. Over the past years, $\chi$ successfully implemented and rolled out various versions of SAP modules in a stage-wise implementation process at its global manufacturing and service sites. In ERP post-implementation periods, $\chi$ immediately benefited from ERP implementation in the form of cost savings and outperforming competitors in price war.

$\lambda$ is a local Dutch service firm in the staff recruitment business with temporary qualified staff working at client sites. $\lambda$ implemented (with $\rho$ as management consultant for implementation) SAP modules in a period of $1 \frac{1}{2}$ years. $\lambda$ spent four months prior and after SAP implementation on (on-the-job) training of staff.

$\varphi$ is an Anglo-French-Dutch service firm specialised in utility, electrical engineering and construction in the Dutch and other European markets. $\varphi$ implemented ERP Acto in a period of nine months in 1998. ERP Acto is particularly custom designed for the electrical and electronic service industry. The objective of implementation was cost savings through integration of internal processes and application of a management support decision-making tool. Most recently, $\varphi$ worked on integration of its business processes at the interface with its preferred suppliers, e-procurement.

$\psi$ is a manufacturing firm with global polymer and plastics production facilities. ERP SAP implementation (and other ERP packages) is part of a continuous development process at $\psi$ aiming at best practices including an advanced TQM system like Six Sigma. They continuously customise ERP packages to respond to the requirements of the internal clients. This case study covers only ERP implementation efforts at the $\psi$ site in Germany (which began in April 1997 and ended in December 1999).

Table 3 Review of Enterprise Resource Planning implementation in four cases (Group 3)

\begin{tabular}{lllll}
\hline Companies & Revenue & ERP vendor & Project budget & ERP modules implemented \\
\hline$\chi$ & Non-disclosure & SAP & Non-disclosure & SAP modules \\
$\lambda-\rho$ & Euro 1.1 billion & SAP & Non-disclosure & SAP \\
$\varphi$ & Non-disclosure & $\begin{array}{l}\text { Acto }+ \text { own } \\
\text { designed }\end{array}$ & Non-disclosure & ACTO \\
$\psi$ & Non-disclosure & SAP & Non-disclosure & SAP/Oracles - WMS/MRP \\
\hline
\end{tabular}




\subsubsection{Group (4)}

In this group (4), two cases were studied from the service sector (Table 4).

$\Delta$ is one of the largest temporary staffing organisations of the world. $\Delta$ has a decentralised organisational structure. It consists of 19 regions. Until December 2001, the $19 \Delta$ regions served all $\Delta$ accounts. In some cases, an account had a national-account manager, but he or she was still reporting to a regional director. In December 2001, $\Delta$ selected 50 'key-accounts' and formed an account-department. The challenge for $\Delta$ was to integrate all front- and back-office technologies. The idea was to have the same information available to all account managers in the company so that every product or service need of the customer could be met.

CRM implies that everyone in the enterprise is focused on the customer (PeopleSoft, 2002). Regardless of the extent of the system implementation, it is necessary to have a strong business focus to ensure the necessary change in processes, organisation, people and culture. CRM would allow $\Delta$ to gather and access information about customers' purchasing histories, preferences, complaints and other data so they could better anticipate what customers would want. The goal was to install greater customer intimacy. Other benefits included faster response to customer inquiries, increased efficiency through automation, in-depth understanding of customers, increased marketing and selling opportunities, identifying the most profitable customers, receiving customer feedback that leads to new and improved products or services and obtaining information that can be shared with business partners.

The $\Delta$ case is a business case analysis and a follow-up to real IT integration implementation in the previous years. $\Delta$ wrote off several million euros a year prior to the business case analysis for CRM implementation. Based on this business case analysis, $\Delta$ tried to secure a successful implementation by reflecting on its experiences in IT integration in CRM implementation.

$K$ case study is also a business case analysis follow-up to an earlier complex IT integration. $K$ is a service provider in the field of retirement for employees mainly in the metal and technical industry. The major investment in restructuring processes, software and hardware infrastructure was to bring a change of structure in internal processes in order to position the customer first in the supply chain of processes and to build a more stable position in the market. $K$ is changing from a closed organisation to an open organisation. The changes in infrastructure included the changes in basic processes and the replacement of the hardware Unix infrastructure with a new IT hardware system. An estimated investment of six million euros and IT staff for the four years duration of project was the estimated cost of implementation of a new system in 2001.

Table 4 Review of Enterprise Resource Planning of Enterprise Resource Planning implementation on two cases (Group 4)

\begin{tabular}{lclll}
\hline Companies & Revenue & ERP vendor & Project budget & ERP modules implemented \\
\hline$\Delta$ & - & CRM & Non-disclosure & CRM \\
$K$ & - & Non-disclosure & Euro $6.0 \mathrm{mln}$ & CRM \\
\hline
\end{tabular}


The changes in business processes and hardware resulted in a competitive advantage through faster response times (i.e. on-line and batch), less vulnerability (i.e. shorter downtimes, quick and complete recovery), a high degree of customer satisfaction and high availability for outsourcing. Replacing the existing complex and tailor-made infrastructure by standardised solutions resulted in a more feasible and economical method of outsourcing basic processes.

\subsection{Comparative analysis within each group of cases}

In the analysis, we compared the same characteristics for all companies, analysing differences in degree of success in implementation while specifying the KSFs in ERP implementation for each firm, the differences in KSFs between services and manufacturing, and the differences in project routes between the two sectors.

\subsubsection{Group (1)}

The main reasons for ERP implementation were

1 to shorten lead times

2 to cut back on personnel

3 to eliminate overhead costs

4 to generate a concise flow of information to other disciplines (Table 5).

In the service sector, ERP was particularly implemented to serve as a supportive instrument to primary processes or the core business processes. The analysis across cases suggested that each firm had a different system and required a different implementation approach. In fact, what was feasible for one firm was not necessarily feasible for another firm. In other words, from a project management perspective, each ERP project required a different business solution, a different approach and a different project route.

A number of positive and negative impacts resulted from ERP implementation in the four case studies of group (1) with positive impacts in

1 integration of internal processes with external processes

2 reducing personnel (e.g. reducing costs of manpower)

3 reducing overhead costs (or the fixed costs)

4 E-strategy synergy

5 partnerships (i.e. sharing information and knowledge)

6 external focus and internal focus

7 lowering MRO costs (e.g. costs of logistics, tooling, etc.)

8 lowering IT costs and other costs

9 application of knowledge management.

and with negative impacts in

1 utilisation of valuable individual participants in ERP implementation

2 required change management 
3 required corporate IT management

4 required training

5 required maintenance management

6 opportunity costs

7 risk of bankruptcy

8 risk of client disappearance.

Table 5 Cross-case analysis of Enterprise Resource Planning implementation project routes (Group 1)

Reasons for ERP adoption (business/technology reasons)

$\beta$-manufacturing

Corporate and organisational planning model

Replacement of project system

Standardisation of

infrastructure

Centralisation of logistics planning

Centralisation of financial services

Requirement to create a lean, flexible organisation, which is able to absorb growth

$\alpha$-service

Y2K (BaaNIV)

SAP report structure (BaaNIV)

Improving report structure

Project management (Pentagon)

Lowering MRO fixed costs

Project content (KSFs)

Project goals (tangible/intangible benefits)

Management involvement

Corporate culture

Report planning

Contingency approach to planning

Full dedication of team members, users/key users

Project planning

Contingency approach to foreseeing the problems

Management involvement

Project management

Management control and ownership

Recognition of strive for organisational fit

Strategic IT integration

Employee dedication
Reduction in costs and reworks

Reduction in manufacturing lead times

Flexible production

Increase in inventory turnover

Sustain the reputation of the most consistent quality producer

Increase flexibility while improving quality

Create greater flexibility to deal with large customers on a pan European basis

Improvement in project control Improvement in report structure Improvement in process of integration and speed of business processes

Lower MRO fixed costs

(the costs of manpower, logistics, tooling, IT costs and hanger costs) Pentagon

Integration of internal processes to external processes, E-strategy synergy

Partnerships, sharing information and knowledge across the supply chain with global clients 
Table 5 Cross-case analysis of Enterprise Resource Planning implementation project routes (Group 1) (continued)

\begin{tabular}{|c|c|c|}
\hline $\begin{array}{l}\text { Reasons for ERP adoption } \\
\text { (business/technology reasons) }\end{array}$ & Project content (KSFs) & $\begin{array}{l}\text { Project goals (tangible/intangible } \\
\text { benefits) }\end{array}$ \\
\hline \multicolumn{3}{|l|}{$\overline{\phi-m a n u f a c t u r i n g}$} \\
\hline $\mathrm{Y} 2 \mathrm{~K}$ & Management involvement & Cost reduction \\
\hline \multirow{7}{*}{$\begin{array}{l}\text { Replacement of old in-house } \\
\text { legacy systems with exact } \\
\text { software package }\end{array}$} & \multirow{4}{*}{$\begin{array}{l}\text { Organisational fit } \\
\text { Innovation strategy } \\
\text { Understanding internal } \\
\text { processes }\end{array}$} & Customer relation support \\
\hline & & Improvement in communication \\
\hline & & with partners \\
\hline & & Improvement in company \\
\hline & \multirow{2}{*}{$\begin{array}{l}\text { Convincing the staff of the } \\
\text { overall benefits of IT } \\
\text { integration to them and to } \\
\text { the firm }\end{array}$} & integration culture \\
\hline & & $\begin{array}{l}\text { Improvement in fulfilment of } \\
\text { commitment }\end{array}$ \\
\hline & $\begin{array}{l}\text { Progress reports and } \\
\text { results reports }\end{array}$ & \\
\hline \multicolumn{3}{|l|}{$\sigma$-service } \\
\hline Cost savings & Management involvement & Cost savings \\
\hline Standardisation & Training & Lead-times \\
\hline Exploitation of hidden assets & \multirow{3}{*}{$\begin{array}{l}\text { Control on progress of } \\
\text { implementation and the } \\
\text { result of stage-wise } \\
\text { implementation }\end{array}$} & Utilising hidden assets \\
\hline Labour intensivity & & Improvement in quality \\
\hline Growth in business & & Reducing reworks/errors \\
\hline
\end{tabular}

Ideally, the concept of implementation should be the adoption of an ERP system into optimally restructured internal processes of a firm. In a successful implementation process of ERP, a commitment to implementation of both technical and non-technical issues is a must. In sum, success or failure of implementation for all firms lies on technical and non-technical factors in; training, communication, teamwork, management decision-making procedures and budgeting.

\subsubsection{Group (2)}

The main reason for ERP implementation was

1 the continuing business expansion

2 generating an accurate and consistent flow of information to other disciplines through integration of business processes

3 process optimisation (Table 6).

Primarily, ERP was implemented to serve as a supportive instrument to primary processes or core business processes to support the expansion of business services from financial services to consulting services, and to eliminate the labour intensity of operations. 
Table 6 Cross-case analysis of Enterprise Resource Planning implementation project routes (Group 2)

\begin{tabular}{|c|c|c|}
\hline $\begin{array}{l}\text { Reasons for ERP adoption } \\
\text { (business/technology reasons) }\end{array}$ & Project content (KSFs) & $\begin{array}{l}\text { Project goals (tangible/intangible } \\
\text { benefits) }\end{array}$ \\
\hline \multicolumn{3}{|l|}{$\mu$-manufacturing } \\
\hline \multirow{2}{*}{$\begin{array}{l}\text { Business expansion, (i.e. large } \\
\text { growth in business and new } \\
\text { business areas) }\end{array}$} & \multirow{3}{*}{$\begin{array}{l}\text { Corporate culture } \\
\text { (organisational behaviour, } \\
\text { and acceptance of changes } \\
\text { on the way of working by } \\
\text { personnel) }\end{array}$} & Visibility \\
\hline & & \\
\hline \multirow{10}{*}{$\begin{array}{l}\text { Integration of business } \\
\text { processes } \\
\text { Business engineering } \\
\text { Process optimisation }\end{array}$} & & Opportunity on new IT systems \\
\hline & \multirow{3}{*}{$\begin{array}{l}\text { Understanding of business } \\
\text { processes and not just ERP } \\
\text { package was of importance }\end{array}$} & \multirow{9}{*}{$\begin{array}{l}\text { Facilitate business expansion } \\
\text { Cost savings } \\
\text { Total integration }\end{array}$} \\
\hline & & \\
\hline & & \\
\hline & $\begin{array}{l}\text { Acquiring/building ERP } \\
\text { implementation knowledge } \\
\text { and skills in-house prior to } \\
\text { roll-out }\end{array}$ & \\
\hline & Management involvement & \\
\hline & $\begin{array}{l}\text { Management understanding } \\
\text { of implementation }\end{array}$ & \\
\hline & $\begin{array}{l}\text { Training (internal personnel } \\
\text { with SAP, suitable training } \\
\text { scheme for participants) }\end{array}$ & \\
\hline & $\begin{array}{l}\text { Information and } \\
\text { communication }\end{array}$ & \\
\hline & Business case analysis & \\
\hline \multicolumn{3}{|l|}{ П-service } \\
\hline \multirow{3}{*}{$\begin{array}{l}\text { Reducing labour intensivity } \\
\text { Expansion of business services } \\
\text { (i.e. business portfolios) }\end{array}$} & Clear problem definition & New business opportunities \\
\hline & \multirow{2}{*}{$\begin{array}{l}\text { Clear scope of } \\
\text { implementation }\end{array}$} & Non-financial data processing \\
\hline & & Tight relation with clients \\
\hline \multirow[t]{10}{*}{$\begin{array}{l}\text { Support of primary processes } \\
\text { Financial data accuracy }\end{array}$} & $\begin{array}{l}\text { Clear implementation } \\
\text { project plan }\end{array}$ & Utilisation and extension of \\
\hline & $\begin{array}{l}\text { Corporate culture or people } \\
\text { resistance }\end{array}$ & $\begin{array}{l}\text { A continuous investment in } \\
\text { professional knowledge }\end{array}$ \\
\hline & $\begin{array}{l}\text { Level of IT skills/ } \\
\text { knowledge }\end{array}$ & \multirow{2}{*}{$\begin{array}{l}\text { A wide range of services offered } \\
\text { to the clients and the specialisation } \\
\text { of those services }\end{array}$} \\
\hline & Training & \\
\hline & Management involvement & A personal relationship with the \\
\hline & $\begin{array}{l}\text { Understanding client } \\
\text { business processes }\end{array}$ & $\begin{array}{l}\text { clients } \\
\text { Intensive contacts with client }\end{array}$ \\
\hline & Pilot test implementation & Qualitative \\
\hline & Integration with IT supplier & \\
\hline & Business case analysis & \\
\hline & $\begin{array}{l}\text { Acquiring/building ERP } \\
\text { implementation } \\
\text { knowledge/skills in-house }\end{array}$ & \\
\hline
\end{tabular}


The analysis suggested that both firms had somehow followed a relatively similar implementation approach despite their differences in terms of manufacturing vs. services and tailor-designed vs. packages. This similarity could be explained with similarity in the components of the project routes. The reasons for ERP adoption and project goals were broadly the same for both cases. From a project management perspective, both ERP implementation projects had a similar business solution approach and a similar ERP implementation project route.

\subsubsection{Group (3)}

In manufacturing, the reasons for ERP implementation were price competition and competitive positioning whereas in the service sector the reasons were integration of business processes, cost savings and improving the quality of services (Table 7).

Table 7 Cross-case analysis of Enterprise Resource Planning implementation project routes (Group 3)

\begin{tabular}{|c|c|c|}
\hline $\begin{array}{l}\text { Reasons for ERP adoption } \\
\text { (business/technology reasons) }\end{array}$ & Project content (KSFs) & $\begin{array}{l}\text { Project goals (tangible/intangible } \\
\text { benefits) }\end{array}$ \\
\hline \multicolumn{3}{|l|}{$\psi$-manufacturing } \\
\hline \multirow{8}{*}{$\begin{array}{l}\text { Efficiency } \\
\text { Global competitiveness } \\
\text { Price competition } \\
\text { Standardisation }\end{array}$} & Key success: & \multirow{8}{*}{$\begin{array}{l}\text { Flexibility in production } \\
\text { Implementation of an effective } \\
\text { maintenance policy (e.g. alignmen } \\
\text { of maintenance policy with } \\
\text { business policy) }\end{array}$} \\
\hline & Management involvement & \\
\hline & Personnel participation and & \\
\hline & $\begin{array}{l}\text { motivation to changes } \\
\text { (e.g. brainstorming teams) }\end{array}$ & \\
\hline & Key failures: & \\
\hline & Personnel cultural resistance & \\
\hline & $\begin{array}{l}\text { Personnel emotional } \\
\text { intelligence }\end{array}$ & \\
\hline & $\begin{array}{l}\text { Leaders' abstractiveness } \\
\text { (emotional intelligence) } \\
\text { towards their management } \\
\text { team could be described by } \\
\text { Changes towards highly } \\
\text { competitive and global } \\
\text { culture }\end{array}$ & \\
\hline \multicolumn{3}{|l|}{$\lambda$ - $\rho$-service } \\
\hline Better qualitative process & Training & Fast and clear processes \\
\hline Standardised processes & Open communication & Lower operational costs \\
\hline \multirow{7}{*}{$\begin{array}{l}\text { Elimination of labour costs } \\
\text { (i.e. cut-backs on personnel } \\
\text { and labour intensivity of } \\
\text { operation) }\end{array}$} & Cooperative attitudes & \multirow{7}{*}{$\begin{array}{l}\text { Sustainable continuity in operation } \\
\text { Lowering reworks from } 5 \text { to } 0.5 \% \\
\text { Standardisation of processes }\end{array}$} \\
\hline & Professional project & \\
\hline & & \\
\hline & $\begin{array}{l}\text { Sticking to original scope } \\
\text { and planning of } \\
\text { implementation }\end{array}$ & \\
\hline & Commitment to success & \\
\hline & $\begin{array}{l}\text { Pilot tests (process } \\
\text { simulation test) }\end{array}$ & \\
\hline & Management involvement & \\
\hline
\end{tabular}


Table 7 Cross-case analysis of Enterprise Resource Planning implementation project routes (Group 3) (continued)

\begin{tabular}{|c|c|c|}
\hline $\begin{array}{l}\text { Reasons for ERP adoption } \\
\text { (business/technology reasons) }\end{array}$ & Project content (KSFs) & $\begin{array}{l}\text { Project goals (tangible/intangible } \\
\text { benefits) }\end{array}$ \\
\hline \multicolumn{3}{|l|}{$\varphi$-service } \\
\hline \multirow{2}{*}{$\begin{array}{l}\text { Total integration of business } \\
\text { processes }\end{array}$} & Key success: & \multirow{2}{*}{$\begin{array}{l}\text { Total integration of business } \\
\text { processes }\end{array}$} \\
\hline & Management involvement & \\
\hline \multirow[t]{7}{*}{ Cost savings } & Stage-wise implementation & \multirow{7}{*}{$\begin{array}{l}\text { Decision support tool } \\
\text { Collaboration with suppliers } \\
\text { E-procurement }\end{array}$} \\
\hline & Training & \\
\hline & $\begin{array}{l}\text { Pre-implementation } \\
\text { planning }\end{array}$ & \\
\hline & $\begin{array}{l}\text { Pilot tests (process } \\
\text { simulation test) }\end{array}$ & \\
\hline & Key failures: & \\
\hline & Personnel resistance & \\
\hline & $\begin{array}{l}\text { Low management } \\
\text { involvement in changes }\end{array}$ & \\
\hline \multicolumn{3}{|l|}{$\psi$-manufacturing } \\
\hline \multirow{2}{*}{$\begin{array}{l}\text { Sustain competitiveness in } \\
\text { global market }\end{array}$} & Management involvement & \multirow{4}{*}{$\begin{array}{l}\text { Reduced IT costs } \\
\text { Integrated system data } \\
\text { Information decision support } \\
\text { system }\end{array}$} \\
\hline & Dedication to best practice & \\
\hline \multirow{2}{*}{$\begin{array}{l}\text { Price competition (i.e. due to } \\
\text { shift of customer focus from } \\
\text { quality based to cost based } \\
\text { product evaluation) }\end{array}$} & and TQM (e.g. Six Sigma) & \\
\hline & $\begin{array}{l}\text { Global professional project } \\
\text { management }\end{array}$ & \\
\hline
\end{tabular}

For service firms, similar to earlier groups, ERP was primarily implemented as a supportive instrument to primary processes, core business processes. The analysis also showed that each company had a different system and it required a different implementation approach. In fact, what was feasible for one company was not necessarily feasible for another company. In other words, from a project management perspective, each ERP project required a different business solution approach and a different project route.

\subsubsection{Group (4)}

For these two service firms, as in earlier groups, ERP was primarily implemented to serve as a supportive instrument to primary processes or core business processes (Table 8).

The analysis also showed that each company had a different system and it required a different implementation approach. In fact, what was feasible for one service firm, it was not necessarily feasible for another service firm. In other words, from a project management perspective, each ERP project required a different business solution, a different approach and a different project route; although for both service firms the strategic business objectives were constructed to meet the clients' demands. 
Table 8 Cross-case analysis of Enterprise Resource Planning implementation project routes (Group 4)

Reasons for ERP adoption (business/technology reasons)

$\Delta$-service

Standardisation

Centralisation

Database management system

Decision support system
K-service

Sustain competitiveness

Developing new services

Outsourcing opportunities

Shorter response times

Reliable infrastructure

Conversion of complex infrastructure to standardised solution

Project goals (tangible and intangible benefits)

Project content $(K S F s) \quad$ intangible benefits)

Simple and fool-proof Customer transparency

Training

Understanding of client

Faster response to customer inquiries

business processes Increased efficiency through

Corporate culture automation

(e.g. employee participation) In-depth understanding of

Strategic approach

customers

Right allocation of resources

Increased marketing and selling opportunities

Identifying the most profitable customers

Receiving customer feedback that leads to new and improved products or services

Obtaining information that can be shared with business partners

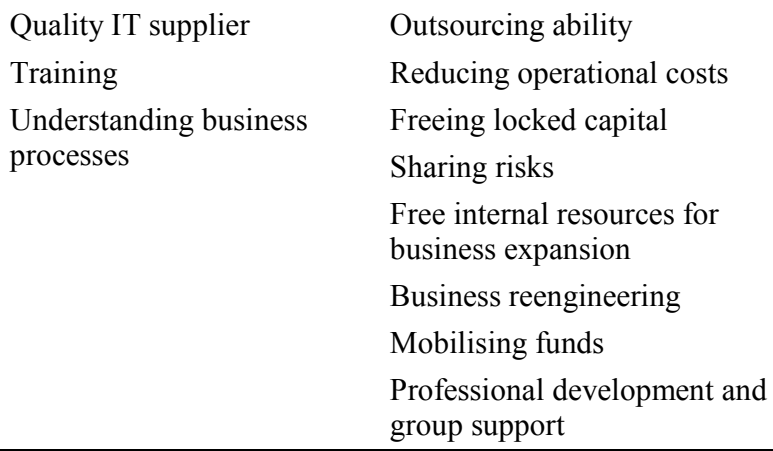

\subsection{Differences in Key Success Factors within each group of cases}

Using a two-dimensional cross-case analysis of KSFs, we looked into the findings on differences between manufacturing and service sectors and differences between tailordesigned and ERP supplier packages.

\subsubsection{Group (1)}

The KSFs that differentiated the process of ERP implementation for the two sectors in this set of cases were:

KSFs in services, but not in manufacturing. Stage-wise ERP implementation (IT integration), strategic approach to ERP implementation (IT integration).

KSFs in manufacturing, but not in services. Innovation strategy, process management and contingency approach to planning. 


\subsubsection{Group (2)}

The KSFs that differentiated the process of ERP implementation between two sectors in these two successful cases were:

KSFs in services, but not in manufacturing. Understanding client business processes, pilot test implementation, clear project implementation plan, clear problem definition and clear scope of implementation.

KSFs in manufacturing, but not in services. Understanding internal business processes.

The common KSFs for these two cases were: corporate culture, management involvement, training, a thorough business case analysis, acquiring and building ERP implementation, internal and external information and communication OR integration with IT supplier.

\subsubsection{Group (3)}

In a cross-case analysis in the service sector, training, pilot tests and process simulation tests, were among the major differences that appeared. These two major differences were also discovered in our review of the literature on the differences between the two sectors. The nature of these two differences was related to the client interaction in product design and development.

The KSFs that differentiated the process of ERP implementation for these four cases were:

KSFs in services, but not in manufacturing. Level and content of training, pilot tests, (pre) implementation planning, open communication.

KSFs in manufacturing, but not in services. Optimal internal business processes (dedication to best practices and TQM-Six Sigma, i.e. focus on internal processes), leaders interest in the long-term consequences of change (emotional intelligence), and global professional project and change management.

The common KSFs for the two sectors included; management involvement, global professional project management, corporate culture and changes towards highly competitive culture and globalisation. From the screening of the first three groups, three vital KSFs arise. Training in content, clear pre-implementation planning and pilot tests are relatively more important KSFs in ERP implementation in services than in manufacturing.

\subsubsection{Group (4)}

In a cross-case analysis, content of training, pilot-test (process simulation tests), understanding client business processes and corporate culture were the four major common KSFs for the two firms at the service sector. The integrated vital KSFs for these two service firms were: simple and fool-proof system, content of training, understanding client business processes, corporate culture (i.e. employees' participation), strategic approach, right allocation of the resources and a quality IT supplier. 


\subsection{Analysis for differences in Enterprise Resource Planning implementation}

\subsubsection{Group (1)}

The qualitative research analysis suggests that the aim of ERP implementation in service sector was restructuring of internal processes towards CRM while the aim of ERP implementation in manufacturing was restructuring of internal processes to shorter lead times.

\subsubsection{Group (2)}

These two cases were evaluated in depth from the beginning of their implementation plan just prior to the millennium in 1997/1998. Both cases applied a rational and a thorough approach to self-designed and SAP package implementation.

In this process, they had a clear implementation strategy and they worked themselves through the invisibility of the project route in a stage-wise operation.

For both cases, there was a clear reasoning for ERP adoption as tool for business expansion. Although the project goals in the two cases differed from each other, the similarity of KSFs in project content was striking. This was suggestive of our initial theory on differences in impact degrees of KSFs. However, the major differences in KSFs were to be found in differences in the nature of business, i.e. differences between manufacturing and service. In these two cases, the differences appeared to be in understanding client business processes for service vs. understanding internal business processes for manufacturing and level/content of training, pilot test (process simulation).

\subsubsection{Group (3)}

In these four large and relatively large international firms in manufacturing and services, we restricted of analysis to the differences between the two sectors. For all four cases, the process of ERP implementation was a continuous development process from one version to a more advanced and user-friendly version complemented with extension of ERP package through customisation. Since, most cases were of multi-sites nature, this research focused at corporate level with one site in mind.

\subsubsection{Group (4)}

The qualitative analysis suggested that the aim of ERP implementation in service sector was restructuring of internal processes towards CRM. In these, two large and relatively large international firms in the service sector, we restricted our analysis to the main project route in ERP implementation. For these two cases, the process of ERP implementation was a continuous development process from one version to a more advanced and more user-friendly version and extension of ERP package through customisation.

We identified more KSFs in ERP implementation in the manufacturing sector than in the service sector. In other words, the KSFs in ERP implementation in manufacturing are the KSFs in ERP implementation in service sector plus a number of additional KSFs, which are only relevant to manufacturing. One interpretation of these results is the presence of differences in KSFs between the two sectors. The other interpretation is that since the manufacturing sector also includes service type activities, the KSFs in ERP 
implementation in the manufacturing sector cover also KSFs in services. However, our approach does not show differences in degree of various KSFs in ERP implementation in either manufacturing or services. In other words, KSFs may be more important in ERP implementation in manufacturing than in the service sector and vice versa. In the literature, we identified a large number of KSFs in ERP implementation in both manufacturing and services. A number of these KSFs were common KSFs for both sectors and a number of them are present either in manufacturing or in the service sector. Most common KSFs are project related factors. This phenomenon suggests that the project management and project structure of the ERP implementation play a critical role in success or failure of an ERP implementation.

The differences in KSFs are more related to the importance of internal issues in the manufacturing sector in comparison to the importance of externally related issues in the service sector. This refers to internal processes for cost savings purposes in manufacturing and the external processes for integration with the client in services. Although all the KSFs could be found in either manufacturing or services, their relative impact in ERP implementation appeared to be different in either service or manufacturing. We suggest that all the KSFs in ERP implementation in manufacturing sector may be present in implementation of ERP in service sector and vice versa. The differences are in impact degrees of the KSFs.

KSFs in manufacturing, but not in services. Understanding internal processes for adaptation, standardisation management perspectives and attitudes towards IS and IT adoption and application, the development of internal IS and IT competencies, internal cost savings strategy, internal customer centric, stage-wise ERP implementation (SAP modules).

KSFs in services, but not in manufacturing. Understanding external processes for adaptation, process optimisation, external revenue strategy and external customer centric.

Common KSFs in both service and manufacturing. Organisational fit, level of process management, management involvement, organisational leadership, project management view include clear implementation plan and constant watchdog on the budget, strategic alignment with IT, information system strategic planning, contingency approach to adoption of information system planning, organisational readiness and people, level of IT integration with business processes. These findings of differences in KSFs make our initial theory on differences in management of ERP implementation between the two sectors, phase after phase more valid. In our literature review, we also identified a set of common KSFs and differences in KSFs in ERP implementation between the two sectors of manufacturing and services.

\section{Discussion, results and conclusions}

We learnt from an empirical and literature review that most common KSFs in ERP implementation for the two sectors were the project related factors, while for the differences in KSFs we learnt that KSFs in services were related to outbound logistics, i.e. external clients, and in manufacturing; the KSFs were related to the internal processes, i.e. internal clients. This analysis also suggests that there is a difference in focus between the sector, with internal processes at the centre in the manufacturing sector and external processes in the service sector. 
In general, in the service sector, the emphasis should be given to processes externally related at the interface with clients' business processes. This suggests the necessity for a tighter link between supplier business processes and the clients and a clear understanding of the clients' needs in the service sector. We observed these unique characteristics in both tailor-designed system and ERP package system in the service sector.

The analysis of cases with either less or more successful ERP implementation provides guidelines for a better understanding of ERP implementation processes. We employed a comparative research case study methodology looking at large, medium and small size firms that were involved in ERP implementation systems. The ERP packages were either supplied by the vendors or tailor-designed by the firms to their requirements over a long period of time.

In our cross-case analysis of cases involving large ERP packages and tailor-designed systems, we made a comparative analysis of the KSFs in ERP implementation for the two sectors (Table 9). An overview of empirical studies suggested that the firms, which initiated the ERP implementation by restructuring their internal processes in a stage-wise ERP implementation, had a more successful ERP implementation.

These two factors of stage-wise ERP adoption and restructuring of internal processes or business re-engineering, together with well-studied firm requirements for IT integration were primarily characteristic of operations at large international firms.

We learnt that project management and change management competencies, project structure, management involvement and ownership, a contingency approach to implementation, understanding internal and external business processes, content of training, change of working culture (i.e. corporate culture) and a better understanding of implementation benefits by the employees were among the KSFs in ERP implementation for the two sectors. A summary of the qualitative research suggests that the firms that underestimated the importance of restructuring their internal processes and its impact on an efficient post-ERP implementation process had less success in implementation. The management team got heavily involved in handling of the implementation processes at firms, which faced fierce competition in the market. The data from the successful firms in the case studies suggested that a thorough business case study and a return on investment analysis by the management prior to the ERP implementation were important KSFs.

We obtained five sets of differences in KSFs (Table 9), distinguishing differences in ERP implementation in the service sector from the manufacturing sector. In our method of analysis, we looked only into those differences in KSFs derived from the differences between manufacturing and services by the comparative analysis of the set of differences in KSFs between groups (1-3) with group (4) (KSFs from only service firms). In this way, we identified a set of KSFs as vital in ERP implementation in the service sector. These KSFs are: understanding client business processes, corporate culture, the level and content of training, clear implementation planning, a strategic approach to ERP implementation and pilot-test customisation of ERP package.

The KSFs found in the literature review were related to various phases of ERP implementation projects for all industries. These KSFs were inevitably connected to the components of the project route in ERP implementation in either manufacturing or service. In our literature review, in search for differences in KSFs in implementation of MRP in manufacturing and ERP in manufacturing and service, we also discovered the main differences in implementation of the two systems in the project related tasks. The differences in project-related tasks refer to differences in project management. These 
differences also supported the theory of differences in project routes in ERP implementation between manufacturing and services.

In order to eliminate the unpredictability, in the starting phase of each ERP implementation, there must be a clear definition of the project route. This way, the project manager will be able to allocate the pieces of the jigsaw at their appropriate location along the project route. With the pieces of jigsaw, we refer to resources and utilisation of the right KSFs within the project content, etc. From a project management perspective, we suggest that our theory of differences will provide a clearer project route in each ERP implementation.

Table 9 Cross-case screening of empirical results on differences

\begin{tabular}{|c|c|c|}
\hline $\begin{array}{l}\text { Logical approach- } \\
\text { narrowing differences }\end{array}$ & $\begin{array}{l}\text { Differences in KSFs - first } \\
\text { validation analysis }\end{array}$ & $\begin{array}{l}\text { Differences in KSFs - second } \\
\text { screening analysis }\end{array}$ \\
\hline Group 1 & $\begin{array}{l}\text { Service from manufacturing. Stage- } \\
\text { wise ERP implementation, strategic } \\
\text { approach to ERP implementation } \\
\text { Manufacturing from service. } \\
\text { Innovation strategy process } \\
\text { management and contingency } \\
\text { approach to planning }\end{array}$ & $\begin{array}{l}\text { Stage-wise ERP adoption } \\
\text { Strategic approach to ERP } \\
\text { implementation }\end{array}$ \\
\hline Group 2 & $\begin{array}{l}\text { Service from manufacturing. } \\
\text { Understanding client business } \\
\text { processes, pilot test implementation, } \\
\text { clear project implementation plan, } \\
\text { clear problem definition, clear scope } \\
\text { of implementation } \\
\text { Manufacturing from service. } \\
\text { Understanding internal business } \\
\text { processes }\end{array}$ & $\begin{array}{l}\text { Understanding client business } \\
\text { processes } \\
\text { Pilot test } \\
\text { Clear implementation planning }\end{array}$ \\
\hline Group 3 & $\begin{array}{l}\text { Service from manufacturing. Level } \\
\text { and content of training, pilot tests, } \\
\text { (pre) implementation planning, } \\
\text { open communication } \\
\text { Manufacturing from service. } \\
\text { Optimal internal business processes } \\
\text { (dedication to best practice and } \\
\text { TQM-Six Sigma, i.e. focus on } \\
\text { internal processes), leaders } \\
\text { conceptual concern (emotional } \\
\text { intelligence) towards changes, } \\
\text { global professional project/change } \\
\text { management }\end{array}$ & $\begin{array}{l}\text { Pilot test } \\
\text { Level and content of training } \\
\text { Clear implementation planning }\end{array}$ \\
\hline Group 4 & $\begin{array}{l}\text { Service. Simple and foolproof, } \\
\text { understanding of client business } \\
\text { processes, corporate culture } \\
\text { (employee participation), strategic } \\
\text { approach to ERP implementation, } \\
\text { right allocation of resources } \\
\text { Service. Good IT supplier, training, } \\
\text { understanding business processes }\end{array}$ & $\begin{array}{l}\text { Understanding client business } \\
\text { processes } \\
\text { Corporate culture } \\
\text { Training } \\
\text { Strategic approach to ERP } \\
\text { implementation } \\
\text { Clear implementation planning }\end{array}$ \\
\hline
\end{tabular}


The fundamental differences in KSFs for ERP implementation between manufacturing and services suggest differences in components of the ERP project route, reasons for adoption, project goals with project contents, i.e. project phases and KSFs, in particular. This has led to the recognition of differences in project management, or project championship, in ERP implementation between manufacturing and services. Basically, we have identified that the ERP implementation process shaped into internally oriented efforts in manufacturing sector and to externally oriented efforts in service sector. With a clear project goal, the traditional project management skills cover planning, scheduling and control of various projects in either manufacturing or service. In ERP implementation, one of the large costs is the hidden opportunity cost of utilisation of key resources in implementation.

The visibility of the project routes and its phases are still under research. For example, in the literature, there is a neglect of bottom-up forces in ERP implementation. The invisibility of the project routes makes project management of ERP implementation still 'rather risky'. However, the fact remains that there is no specific formula to a successful ERP implementation, although, the skills and experiences learnt on various cases could be the key factor in success of any ERP implementation project.

The results of this research work match with other research activities in which the researchers claim organisational fit as a KSF in any ERP implementation. In a number of publications, organisational misfits to software packages has been made responsible for ERP implementation failures. The same researchers argue for the right vendor approach, internal restructuring approach, etc., a solution to failure risks. Shang and Seddon (2002) ranked the organisational benefits as the lowest beneficial pillar in ERP implementation. This might suggest that researchers have neglected the long-term impact of ERP implementation and its benefits in other dimensions (e.g. competitiveness) as established in this research work. However, in many ERP implementations the outcome implementation is measured in the firm short-term profitability. These facts open the discussion of whether the short-term impact of ERP implementations may be taken as the basis for to determine benefits of any ERP implementation.

New arising issues are about intangible and tangible benefits from ERP implementation. The result of what went wrong and what went right in implementation processes could be the trade-off between intangible and tangible benefits, competitive position, global positioning in the market in short and long period. Literature suggests that substantial investments in shaping pre-implementation attitude of personnel did not give the desired results. Similarly, the research results suggested that longitudinal stagewise ERP implementation had a greater impact on changing attitudes towards ERP capabilities, values, acceptance and timing than high levels of pre-implementation involvement and investments as in Big-Bang implementation projects.

\section{References}

Al-Mashari, M., Al-Mudiningh, A. and Zairi, M. (2003) 'Enterprise resource planning: a taxonomy of critical factors', European Journal of Operational Research, Vol. 146, pp.352-364.

Kwon, T.H. and Zmud, R.W. (1987) 'Unifying the fragmented models of information systems implementation', in R.J. Boland and R.A. Hirschheim (Eds), Critical Issues in Information Systems Research. (pp.227-251) New York, NY: John Wiley. 
Markus, M. and Tanis, C. (2000) 'The enterprise systems experience-from adoption to success', in R.W. Zmud (Ed.), Framing the Domains of IT Research: Glimpsing the Future Through the Past. Cincinnati, OH: Pinnaflex Educational Resources.

Nah, F., Zuckweller, K., and Lau, J. (2003) 'ERP implementation: chief information officers' perceptions of critical success factors', Int. J. Human-Computer Interaction, Vol. 16, pp.5-22.

Shang, S. and Seddon, P.B. (2002) 'Assessing and managing the benefits of enterprise systems: the business manager's perspective', Information Systems Journal, Vol. 12, pp.271-299.

Somers, T., Nelson, K. and Ragowsky, A. (2000) 'Enterprise Resource Planning (ERP) for the next millennium: development of an integrative framework and implications for research', Paper presented in the Proceedings of the Americas Conference on Information Systems, Long Beach, CA.

Umble, E., Hatt, J., Umble R. and Michael, M. (2003) 'Enterprise resource planning: implementation procedures and critical factors', European Journal of Operation Research, Vol. 146, pp.241-257.

\section{Literature}

Abdinnour-Helm, S. and Lengnick-Hall, M. (2003) 'Pre-implementation attitudes and organisational readiness for implementing an enterprise resource planning system', European Journal of Operational Research, Vol. 146, pp.258-273.

Bailey, A. (1998) 'Uh-Oh, It's a computer systems project', IEEE Engineering Management Review, Vol. 26, pp.21-25.

Bingi, P., Sharma, M. and Godla, J. (1999) 'Critical issues affecting an ERP implementation', Information Systems Management, Vol. 16, pp.7-14.

Bowen, D. and Schneider, B. (1988) 'Services marketing and management: implications for organizational behavior', in B.A. Staw and L.L. Cummings (Eds), Research in Organizational Behavior (pp.43-80). Greenwich, CT: JAI Press.

Bowen, J. and Ford, R. (2002) 'Managing service organizations: does having a 'thing' make a difference?', Journal of Management, Vol. 28, pp.447-469.

Brehm, L., Heinzl, A. and Markus, M. (2001) 'Tailoring ERP systems: a spectrum of choices and their implication, Paper presented in the Proceedings of the 34th annual Hawaii international conference on system sciences, January 2001.

Brinkkemper, S. (2001) 'Method engineering, web-enabling', van methoden voor Systeemontwikkeling. Ten Hagen Publishing.

Brown, A. (2001) Customer Relationship Management. New York, NY: John Wiley and Sons.

Burn, J. (1997) A professional balancing act: walking the tightrope of strategic alignment', in C. Sauer and P.W. Yetton (Eds), Steps to Future Fresh Thinking on the Management of IT-based Organizational Transformation. San Francisco, CA: Jossey-Bass.

Burn, J. and Szeto, C. (2000) 'A comparison of the views of business and IT management on success factors for strategic alignment', Information and Management, Vol. 37, pp.197-216.

Caldeira, M. and Ward, J. (2003) 'Understanding the successful adoption and use of IS/IT in SMEs: an explanation from Portuguese manufacturing industries, Information Systems Journal, Vol. 12, pp.121-152.

Chen, W. (1996) 'Managing an FMS project: a case study', Project Management Journal, Vol. 27, pp.12-21.

Collier, D. (1987) Service Management. Englewood Cliffs, NJ: Prentice Hall, Inc.

Cramer, Y. (1998) 'Bedrijven persen zich in ERP-software', Intermediair, Vol. 34, pp.145-147.

Davenport, T. (2000) Mission Critical: Realizing the promise of enterprise systems. Boston, MA: Harvard Business School Press.

Deloitte and Touche (1998) The software industry, Annual Report. 
Everdingen van, Y., Hillegersberg van, J. and Waarts, E. (2000) 'ERP adoption by European midsized companies', Communications of the ACM, Vol. 43, pp.27-30.

George, W. and Gronroos, C. (1991) Developing customer-conscious employees at every Level, in C.A. Congram (Ed.), The AMA handbook of marketing for the service industry, Internal marketing (pp.85-100). New York, NY: Amacom.

Griffith, T.L., Zammuto, R.F. and Aiman-Smith, L. (1999) 'Why new technologies fail?', Industrial Management, Vol. 41, pp 29-34

Henderson, J. and Venkatramanm, N. (1993) 'Strategic alignment: leveraging information technology for transforming organizations', IBM Systems Journal, Vol. 32, pp.4-16.

Heo, J. and Han, I. (2003) 'Performance measure of Information System (IS) in evolving computing environments: an empirical investigation', Information and Management, Vol. 40, pp.243-256.

Hong, I. (2002) 'A new framework for inter-organisational systems based on the linkage of participants' roles', Information and Management, Vol. 39, pp.261-270.

Jitpaiboon, T. and Kalaian, S. (2005) 'Analyzing the effect of top management support on Information System (IS) performance across organizations and industries using hierarchical linear modeling', Journal of International Technology and Information Management, Vol. 14, pp.131-143.

Kalczynski, P. (2005) 'Time dimension for business news in the knowledge warehouse', Journal of International Technology and Information Management, Vol. 14, pp.21-32.

Kumar, R. (2002) 'Managing risks in IT projects: an options perspective', Information and Management, Vol. 40, pp.63-74.

Langeard, E. and Eiglier, P. (1983) 'Strategic management of service development, emerging perspectives on services marketing', in M. Venkatesan, D. Schmalensee and C. Marshall (Eds), Creativity in Services Marketing: What's New, What Works, What's Developing. Chicago, IL: American Marketing Association.

Legare, T. (2002) 'The role of organizational factors in realizing ERP benefits', Information Systems Management, Vol. 19, pp.21-41 (Fall).

Lovelock, C. and Wright, L. (1999) Principles of Service Marketing and Management. New Jersey, NJ: Prentice Hall.

Lovelock, C. and Young, R. (1979) 'Look to consumers to increase productivity', Harvard Business Review, Vol. 57, pp.168-178.

Lyytinen, K. and Hirschheim, R. (1987) 'Information systems failures - a survey and classification of the empirical literature', Oxford Surveys in Information Technology, Vol. 4, pp.257-309.

Mabert, V., Soni, A. and Venkataramanan, M. (2003) 'Enterprise resource planning: managing the implementation process', European Journal of Operational Research, Vol. 146, pp.302-314.

Mandal, P. and Gunasekran A. (2003) 'Issues in implementing ERP: a case study', European Journal of Operational Research, Vol. 146, pp.274-283.

Markus, M., Tanis, C. and van Fenema, P. (2000) 'Multisite ERP implementations', Communications of the ACM, Vol. 43, pp.42-46.

McAfee, A. (1999) 'The impact of enterprise resource planning systems on company performance', Paper presented in the Proceedings of Wharton Electronic Supply Chain Conference, Philadelphia, December.

Palaniswamy, R. and Tyler, F. (2000) 'Enhancing manufacturing performance with ERP systems', Information Systems Management, Vol. 17, p. 43.

Salimi, F., Dankbaar, B. and Davidrajuh, R. (2006a) 'A comprehensive study on the differences between MRP and ERP implementation', Communications of IIMA, Vol. 6, pp.83-94 (ISSN: 1543-5970).

Salimi, F., Dankbaar, B. and Davidrajuh, R. (2006b) 'A comprehensive study on the differences in ERP implementation between manufacturing and service industry', Journal of International Technology and Information Management, Vol. 15, pp.19-30. 
Shanks, G., Parr, A., Hu, B., Corbitt, B., Thanasanki, T. and Seddon, P. (2000) 'Differences in critical success factors in ERP systems implementation in Australia and China: a cultural analysis', Paper presented in the Proceedings of the 8th European Conference on Information Systems (537-544). Vienna, Austria.

Shetty, W. and Ross, J. (1985) 'Quality and its management in service businesses', Industrial Management, Vol. 27, pp.7-12.

Shostack, G. (1987) Service positioning through structural change, Journal of Marketing, Vol. 51, pp.34-43.

Slater, D. (1999) 'An ERP package for you, and you, and even you', CIO Magazine, February 15.

Soh, C., Kien, S. and Tay-Yap, J. (2000) 'Cultural fits and misfits: is ERP a universal solution?', Communications of the ACM, Vol. 43, pp.47-51.

Swan, J., Newell, S. and Robertson, M. (1999) 'The illusion of 'best practice' in information systems for operations management', European Journal of Information Systems, Vol. 8, pp.284-293.

Volkoff, O. (1999) 'Using the structural model of technology to analyse an ERP Implementation', Paper presented in the Proceedings of the Academy of Management' 99 Conference.

Whitten, D. (2004) 'Information systems service quality measurement: the evolution of the SERVQUAL instrument', Journal of International Technology and Information Management, Vol. 13, pp.181-191.

Zeitmal, V. (1981) 'How consumer evaluation processes differ between goods and services', in J.H. Donnelly and W.R. George (Eds), Marketing of Services. Chicago, IL: American Marketing Association Proceedings Series. 